\title{
The consumption of tea and coffee in Turkey and emerging new trends
}

\author{
Oya Yildirim* (D) and Oya Berkay Karaca (10)
}

\begin{abstract}
The aim of this study is to determine the tea and coffee consumption habits of individuals in Adana and Izmir and to identify how the new trends are effective in consumption patterns. Therefore, the research is based on a comparison of two cities with distinctive culinary culture. Questionnaire technique was used to collect the data. Surveys were administered to 806 people in Adana and Izmir, Turkey. The research shows that tea is preferred in Adana (63.3\%), whereas participants in Izmir opt for coffee (53.4\%). The ratio of tasting international regional coffees is higher in Izmir than in Adana. In both cities, black tea and Turkish coffee are among the most consumed drinks. Despite the increasing tendency of foreign beverages due to the impact of globalization, the local people kept their interest in tea and Turkish coffee drink which is a component of the national intangible cultural heritage of Turkey. It is recommended that foreign businesses should include these traditional drinks on the menu.
\end{abstract}

Keywords: Consumption habits, Tea, Coffee, Turkey

\section{Introduction}

Intangible cultural heritage is defined as "practices, representations, narratives, knowledge, skills and related tools, materials and cultural spaces that communities, groups and, in some cases, individuals define as part of their cultural heritage" [1]. Traditional drinks are also classified as the intangible cultural heritage, and they are described as beverages produced by using region-specific ingredients that may have different regional presentation techniques and cultural characteristics [2].

Tourism marketing strategy is intertwined with the localization. For instance, multinational companies in Turkey such as McDonald's (Turkish meatballs for Turkey market, spicy Big Mac, Ayran) [3], Starbucks (Turkish coffee and various teas) and the Dominos (Turkish, Kayseri ateşi, Konyalım pizzas) localize the products in their menus as a marketing strategy. Although these companies follow a standard menu policy in all countries, they

*Correspondence: oyabayram_33@hotmail.com; oyildirim@cu.edu.tr School of Tourism and Hotel Management, Cukurova University, Adana, Turkey

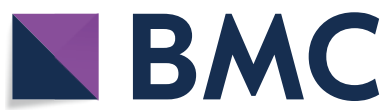

(c) The Author(s) 2022. Open Access This article is licensed under a Creative Commons Attribution 4.0 International License, which permits use, sharing, adaptation, distribution and reproduction in any medium or format, as long as you give appropriate credit to the original author(s) and the source, provide a link to the Creative Commons licence, and indicate if changes were made. The images or other third party material in this article are included in the article's Creative Commons licence, unless indicated otherwise in a credit line to the material. If material is not included in the article's Creative Commons licence and your intended use is not permitted by statutory regulation or exceeds the permitted use, you will need to obtain permission directly from the copyright holder. To view a copy of this licence, visit http://creativecommons.org/licenses/by/4.0/. 


\section{Literature review}

\section{Tea culture and tea consumption in Turkey}

Tea is the most popular drink consumed after water [5]. China and India are regarded as the homeland of tea. From the sixteenth century onwards, it spread to European countries and from there to the rest of the world [4]. Formerly considered a relaxing, enjoyable and warming beverage, tea has been associated with relaxation and clarity of mind [5]. Turkey was the most tea-consuming country in the world with approximately 6.96 kilos in 2016 . This figure is 1.25 kilos per person per year in China [6]. Turkey ranks 7 th in the world in terms of the size of tea cultivation land, 5th in dry tea production and 1 st in per capita tea consumption in 2019. In 2020, $1.445 .181 \mathrm{~kg}$ of fresh tea was processed and 280.000 tons of dry tea was obtained. Of the fresh tea, $46.75 \%$ by the private sector and $53.25 \%$ by the government-owned Çaykur was processed [7]. Tea is grown on the coastline from the city of Rize to the Georgian border in the Black Sea region in the north of the country. Turkey's 2020 production period's tea production areas are $66.4 \%$ in Rize, $20.3 \%$ in Trabzon, 10.8\% in Artvin and 2.4\% in Giresun [8]. Many families in Turkey make a living from tea farming [9].

Turks met with tea in Central Asia before entering Anatolia in the eleventh century [10]. Turkish people are known for their hospitality, and serving tea to guests is very common in Turkish culture. When considered together with its teapot, thin-waisted glass, teaspoon, saucer and brewing method, Turkish tea, which is the symbol of friendship and hospitality, has a traditional feature. In Turkey, the day starts with tea and ends with tea. Since Turks always offer tea to their guests, it is customary for every bride to have a guest tea set in her dowry. Tea is the main drink of Turkishstyle breakfast. In addition, tea is as vital a function as drinking soup or eating bread for Turks [9].

Turks consume $65 \%$ of tea at home, $13 \%$ at work, $11 \%$ in hospitality, $5 \%$ in cafes, $4 \%$ in coffees and $2 \%$ in schools. In workplaces, there are tea vendors in charge of preparing tea and similar beverages, and there are "çay ocağı" (tea houses) in the bazaars and inns that serve drinks to the shops [9]. In every province in Turkey, there are also "çay bahçesi" (tea gardens) where all non-alcoholic hot or cold drinks can be served, where you can read newspapers or books, meet friends to chat or play backgammon okey. Tradesmen usually offer a Turkish tea to every customer as a sign of friendship and hospitality, whether they sell something or not. Apart from the tea gardens where people sit down and get service, there are also tea houses where tea is made and distributed to the shops by one person, where there are sales shops and customers.
Turkish-style tea is brewed with ground roasted black tea in a teapot or samovar over continuous boiling water and served in small glasses known as distinctive thin waist (Fig. 1). The ideal ratio of tea pouring from the "demlik" (top of the teapot) to the glass and the hot water pouring from the kettle (bottom of the teapot) to the glass is described as "rabbit blood". For children, the tea obtained by adding cold water to hot tea is called "pasha tea", and the transition from "pasha tea" to "rabbit blood tea" symbolizes the transition from childhood to adulthood. If sugar is desired in the tea, it is added later while it is in the glass [9].

\section{Turkish coffee culture and tradition}

Although coffee culture is considered as a sub-category of culinary culture, it has its own tools, techniques, sociality, space, economy and identity [11]. The homeland of coffee, which dates back to B.C 900, is known today as the geography of Ethiopia and Kenya. The invention of instant coffee in 1901, the first coffee machine in 1910, the first coffee grinder in the 1920s and the first automatic espresso machine in 1933 increased the coffee consumption all over the world [12]. Coffee consumption is becoming widespread because of the effort to differentiate and classify itself with the effect of developing technology. Thus, coffee consumption is consumed both in brand coffee shops and with coffee machines that are becoming more common at home, or it can be buy take away [13]. The consumption habits of individuals are shaped according to global culture; global coffee brands also structure their marketing and brand strategies by considering the consumption habits of the society [14].

Although coffee is not grown in Turkey, "Turkish coffee" is known worldwide for its unique cooking technique and presentation [15], and since 2013, "Turkish Coffee and Tradition" has been included on the Representative List of Intangible Cultural Heritage of Humanity [16]: "The tradition itself is a symbol of hospitality, friendship, refinement and entertainment that permeates all walks of life. An invitation for coffee among friends provides an opportunity for intimate talk and the sharing of daily concerns. Turkish coffee also plays an important role on social occasions such as engagement ceremonies and holidays; its knowledge and rituals are transmitted informally by family members through observation and participation. Turkish coffee is regarded as part of Turkish cultural heritage: it is celebrated in literature and songs, and is an indispensable part of ceremonial occasions". The characteristics of Turkish coffee, which are stated in the international registration with UNESCO, meet the five basic criteria determined by the French for inscription of a gastronomic meal on the Representative List [17]. Turkish coffee is a cultural value that has an identity handed 


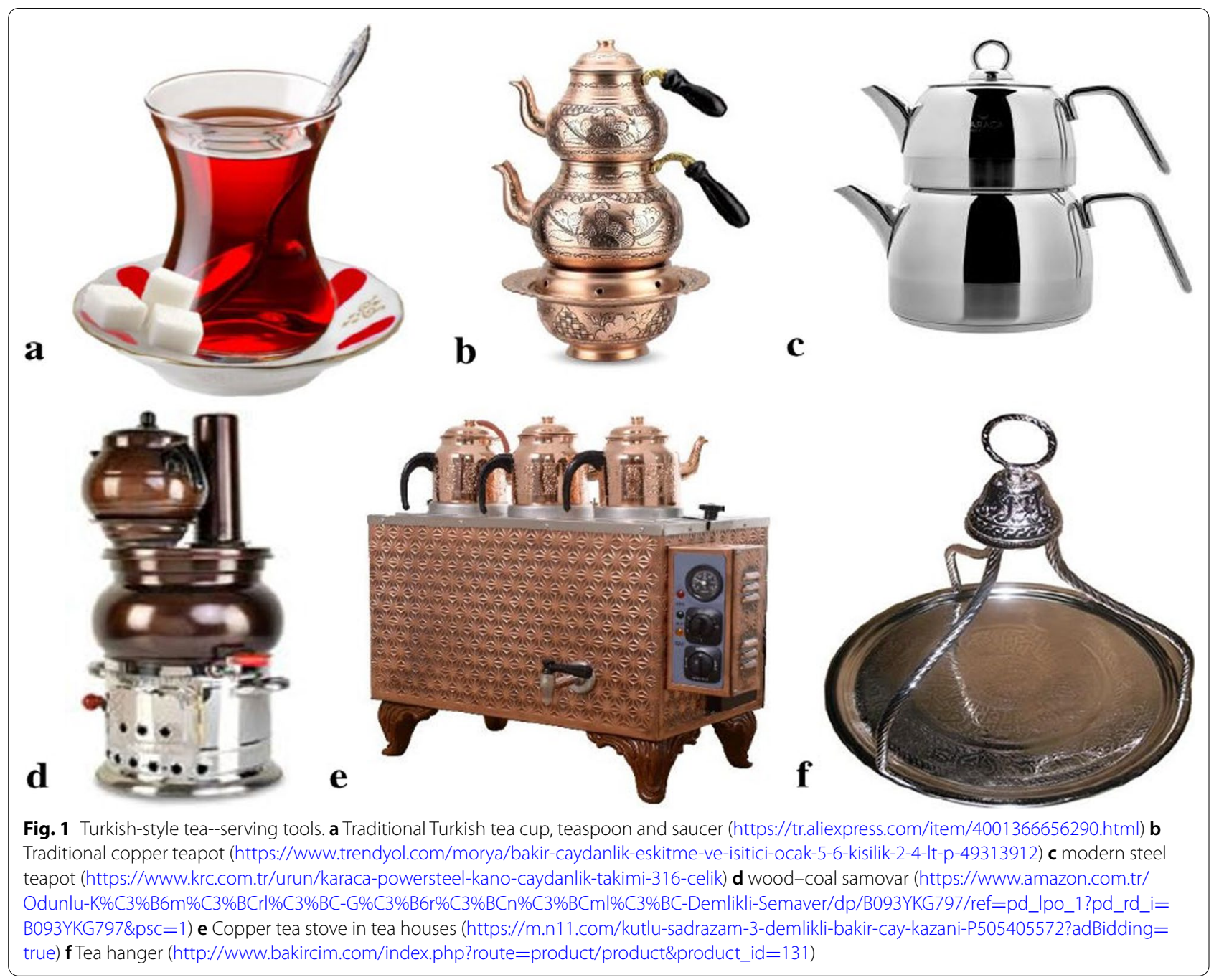

down from generation to generation, contributes to mutual respect and intercultural dialogue, is promoted and protected, and registered in the intangible cultural heritage inventory.

In this way, "Turkish Coffee" has become one of Turkey's internationally registered brands. Turkish coffee, which is stated in various sources that its first use was started by the Ottomans in the early 1500 s, became widespread during the reign of Sultan Suleiman, and the first coffeehouse was opened in Tahtakale area, Istanbul, in 1555 [18] (Fig. 2). In Turkey, as in the cities, there is a village coffee house in every village where the people of the village gather, chat and play card games. Although everyone goes to the tea garden, women do not usually go to village coffee houses, except in the west of Turkey. There is also a strong link between coffee and cigarettes.

In ancient times, the elements used in the presentation of coffee ceremonies can be unique works of art (Fig. 3). The Turkish word for breakfast is derived from "kahve-altı", meaning pre-coffee [19]. Turkish coffee is prepared with high-quality moderately roasted Arabica coffee beans. Unlike the filter coffees traditionally consumed in the West, the desired foam Turkish coffee, which is extremely finely ground, is prepared by adding cold water and sugar to the "cezve" (coffee pot) and boiling it slowly on the stove [18]. There is more than one "fincan" (cup) set in every house in Turkey, and fincan had no handles in traditional when first used until the nineteenth century. Handleless cups were served by putting them in sleeves called "zarf" (envelopes) in order not to burn hands. Coffee was roasted on the "kahve tavası" (coffee skillet) and ground fresh [19] (Fig. 3).

Coffee served with a glass of water and Turkish delight in a small glass is a symbol of hospitality, friendship, kindness and fun and is mostly drunk in coffee houses or homes where people meet to chat, share news and read books [16]. For Turkish society, coffee has many meanings and ritual uses, which are explained below: 


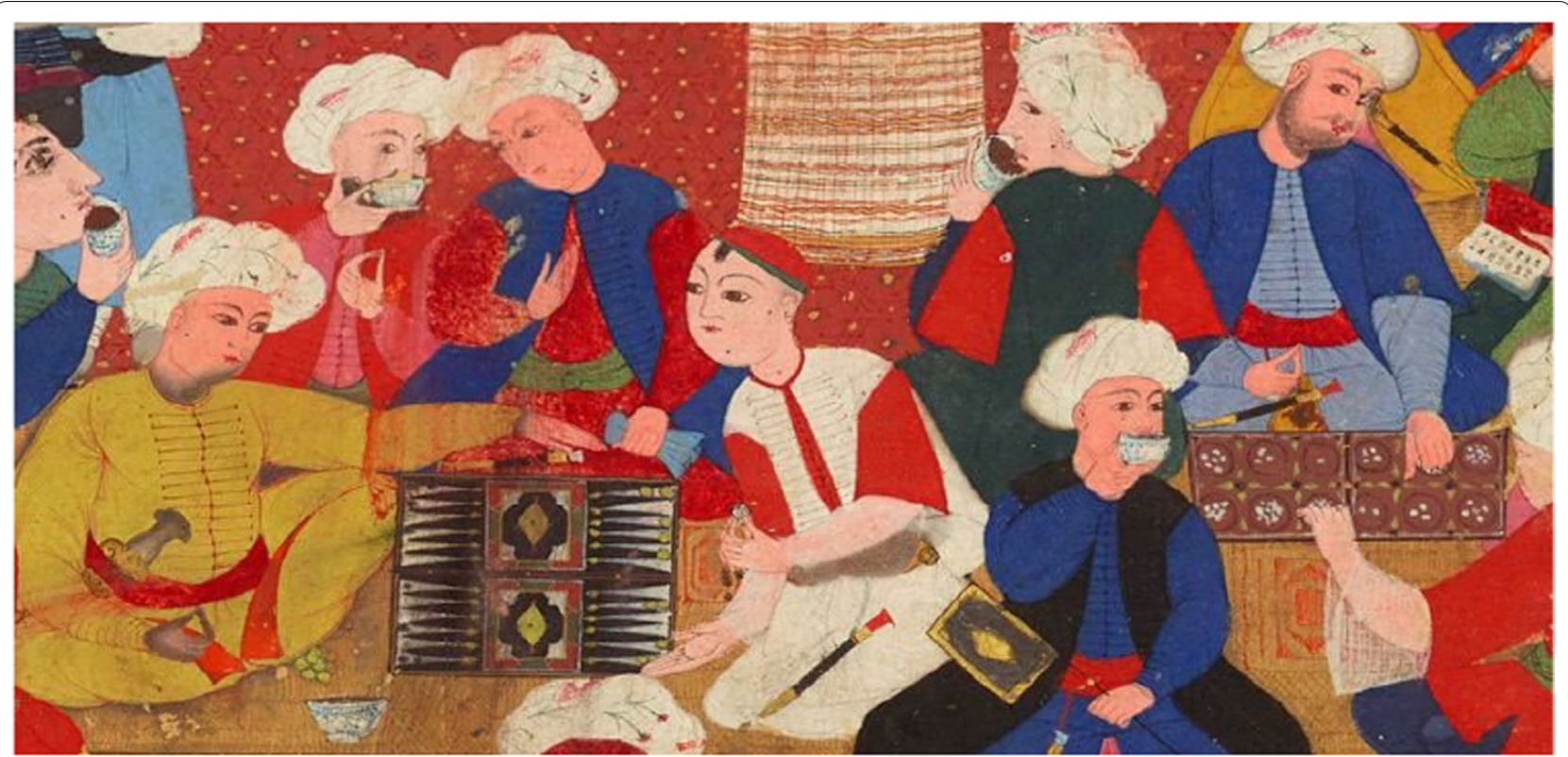

Fig. 2 Coffee and coffee houses in Ottoman and Safavid lands, 1500-1800 (https://sites.Isa.umich.edu/khamseen/short-form-videos/2021/ coffee-and-coffeehouses-ottoman-safavid-lands/)

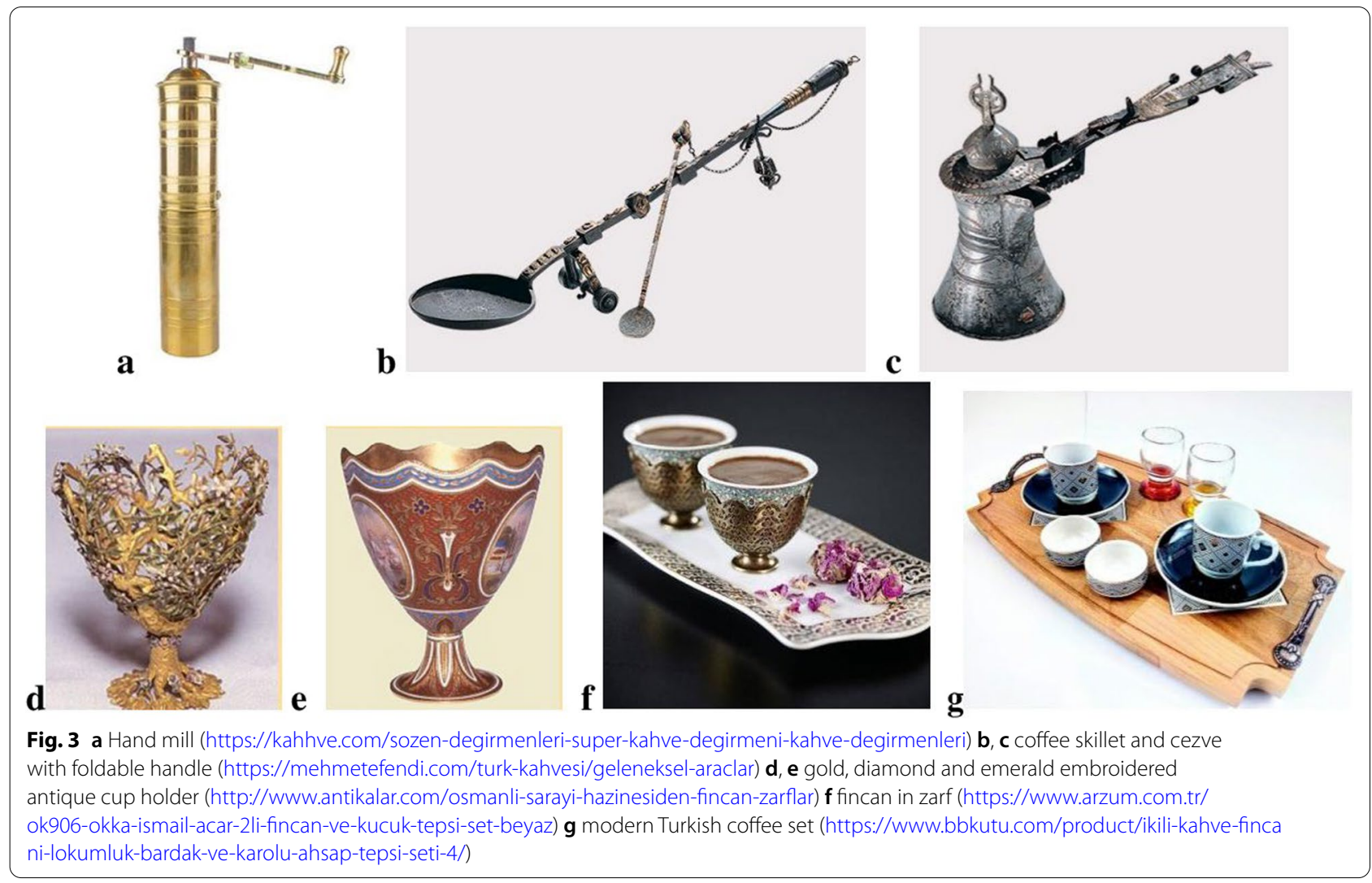


Fortune telling with coffee: After drinking the coffee, the remaining grounds in the cup are turned clockwise several times and the saucer is covered and turned upside down. After it has cooled completely, the shapes formed by the grounds in both the cup and the plate are interpreted by fortune-tellers (interpreters) or friends. It is left on a wedding ring or other gold ring to allow the cup to cool quickly (Fig. 4).

Marriage rituals (Girl request ceremony): The brideto-be makes Turkish coffee to the groom and his family and is evaluated according to how well she prepares and presents Turkish coffee. The bride-to-be just puts a lot of salt in the groom's coffee, and the groom is expected to drink this salty coffee to prove what he will endure for the bride.

Traditional chat meetings: The idiom "A cup of coffee commits one to forty years of friendship", which expresses that Turkish coffee has become the symbol of friendship and conversation and Turkish proverb "souls are after neither coffee nor coffee houses; they are after close companionship; coffee is an excuse" is frequently used in the country.

There are so many coffee types consumed in Turkey. Some of them are Yemen, menengiç (Pistacia terebinthus), Nigella sativa, carob, kenger, okra, almond [20], myrrh, dibek, cilveli [21], çedene [22] and chickpea [23] coffees are among the other types of coffee consumed in Turkey. Ulusoy [24] stated that Turkish coffee is preferred more than foreign coffees.

Although Turkish coffee has an important place in Turkish tradition, instant coffee consumption has increased in recent years. According to the International Coffee Organization, coffee consumption in Turkey has increased by an annual average of $15.6 \%$. Therefore, both national and international coffee chains have increased their investments in Turkey. Starbucks, Tchibo, Caffe Nero, Gloria Jeans, MOC, Federal Coffee, Petra, Kahve

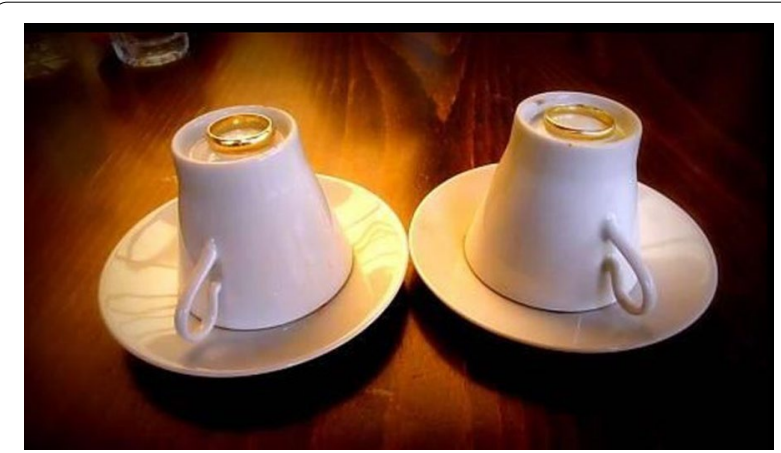

Fig. 4 Cups prepared for fortune telling (https://ich.unesco.org/en/ RL/turkish-coffee-culture-and-tradition-00645)
Dünyası, Kahve Diyarl, Coffee Mania and Kronotrop are among the fastest growing brands. According to 2020 data, there are 523 Starbucks branches in Turkey, and Turkey is the second country with most Starbucks branches in Europe [25]. For all these reasons, it is desired to examine how these trends in coffee consumption affect consumer preferences for traditional Turkish coffee and tea.

\section{Methods}

The data were collected through a questionnaire form which was formed deriving from the literature. The questionnaire includes six demographic information questions and a total of 26 questions about tea and coffee varieties consumption habits of the participants. The sample of the study consists of the participants in the food and beverage establishments in Adana and Izmir city centre. Both are metropolitan cities, which make them feasible for data collection. These two cities have different culinary traditions and have diverse and sufficient number of restaurants/and cafes. İzmir (in the west) is Turkey's third and Adana (in the south) is the sixth largest city [26]. Since there is no list of customers coming to these enterprises, the research aimed to reach the sample size of 384 units calculated by the unlimited universe formula used for the rate by using the easy sampling method (variance with the highest ratio (p: 0.5) considering 0.05 error margin). The data were collected between March and June 2016, and 806 face-to-face questionnaires were administered (467 questionnaires in Adana and 339 in İzmir). The data were edited and statistical methods such as frequency and percentage were used for descriptive analysis. Chi-square analysis was used to determine whether there was a difference between the participants from the two cities in terms of tea and coffee consumption habits. The limitation of the study is the collection of data from two cities representing two different regions of Turkey, rather than the whole of Turkey.

\section{Results and discussion}

Participants were based in İzmir (42.1\%) and in Adana (57.9\%). Table 1 summarizes the demographic characteristics of the participants. The number of men participating in the study was higher in both cities. The participants were mostly students, and this was followed by private sector employees in the second place. Most of the respondents had bachelor's degree, and this was followed by high school and associate degree holders. While the participation rate of those aged $16-30$ was $62.5 \%$ in Adana, it was $70.2 \%$ in İzmir. Young people prefer food and beverage enterprises in both cities, but when the two cities are compared, the participation of young people in İzmir is higher. This result aligns with the finding 
Table 1 Distribution of participants by demographic variables

\begin{tabular}{|c|c|c|c|c|}
\hline & \multicolumn{2}{|c|}{ Adana } & \multicolumn{2}{|c|}{ İzmir } \\
\hline & $F$ & $\%$ & $F$ & $\%$ \\
\hline \multicolumn{5}{|l|}{ Gender } \\
\hline Female & 223 & 47.8 & 150 & 44.2 \\
\hline Male & 244 & 52.2 & 189 & 55.8 \\
\hline Total & 467 & 100 & 339 & 100 \\
\hline \multicolumn{5}{|l|}{ Pearson $x^{2}: 0.970$, s.d.: $1, p: 0.352$} \\
\hline \multicolumn{5}{|l|}{ Occupation } \\
\hline Student & 203 & 43.6 & 117 & 34.5 \\
\hline Tourism sector employee & 11 & 2.3 & 15 & 4.4 \\
\hline Artisan & 31 & 6.7 & 39 & 11.5 \\
\hline Public sector employee & 82 & 17.6 & 32 & 9.4 \\
\hline Private sector employee & 84 & 18.0 & 73 & 21.5 \\
\hline Retired & 9 & 1.9 & 13 & 3.8 \\
\hline Housewife & 28 & 6.0 & 30 & 8.8 \\
\hline Other & 18 & 3.9 & 20 & 5.9 \\
\hline Total & 466 & 100 & 339 & 100 \\
\hline \multicolumn{5}{|l|}{ Pearson $x^{2}: 32.462$, s.d.: 9, p: $0.000<0.05$} \\
\hline \multicolumn{5}{|l|}{ Age group } \\
\hline $16-30$ & 290 & 62.5 & 238 & 70.2 \\
\hline $31-40$ & 95 & 20.5 & 61 & 18.0 \\
\hline $41-50$ & 48 & 10.3 & 26 & 7.7 \\
\hline 51 and more years & 31 & 6.7 & 14 & 4.1 \\
\hline Total & 464 & 100 & 339 & 100 \\
\hline \multicolumn{5}{|l|}{ Pearson $x^{2}: 6.186$, s.d.: $3, p: 0.103$} \\
\hline Married & 164 & 35.1 & 120 & 36.0 \\
\hline Single & 303 & 64.9 & 213 & 64.0 \\
\hline Total & 467 & 100 & 333 & 100 \\
\hline \multicolumn{5}{|l|}{ Pearson $x^{2}: 0.007$, s.d.: $1, p: 0.934$} \\
\hline \multicolumn{5}{|l|}{ Education } \\
\hline Illiterate & 1 & 0.2 & 2 & 0.6 \\
\hline Primary education & 15 & 3.2 & 5 & 1.5 \\
\hline Secondary education & 12 & 2.6 & 10 & 2.9 \\
\hline High school & 103 & 22.1 & 112 & 33.0 \\
\hline Associate degree & 80 & 17.2 & 66 & 19.5 \\
\hline Bachelor's degree & 249 & 53.4 & 127 & 37.5 \\
\hline Postgraduate & 6 & 1.3 & 17 & 5 \\
\hline Total & 466 & 100 & 339 & 100 \\
\hline \multicolumn{5}{|l|}{ Pearson $x^{2}: 32.862$, s.d.: 6, p: $0.000<0.05$} \\
\hline \multicolumn{5}{|l|}{ Income } \\
\hline Low & 55 & 11.8 & 9 & 2.7 \\
\hline Bottom of the middle & 14 & 3.0 & 78 & 23.0 \\
\hline Middle & 287 & 61.6 & 181 & 53.4 \\
\hline Above of the middle & 95 & 20.4 & 64 & 18.9 \\
\hline High & 15 & 3.2 & 7 & 2.1 \\
\hline Total & 466 & 100 & 339 & 100 \\
\hline Pearson $x^{2}: 92.820$, s.d.: $4, p: 0.000<0.05$ & & & & \\
\hline
\end{tabular}

Table 2 Participants' basic ideas on tea and coffee

\begin{tabular}{|c|c|c|c|c|}
\hline & \multicolumn{2}{|c|}{ Adana } & \multicolumn{2}{|c|}{ İzmir } \\
\hline & $F$ & $\%$ & $F$ & $\%$ \\
\hline \multicolumn{5}{|l|}{ Top three consumed beverages* } \\
\hline Tea & 347 & 74.0 & 201 & 59.3 \\
\hline Water & 235 & 50.1 & 162 & 47.8 \\
\hline Turkish coffee & 222 & 47.3 & 207 & 61.1 \\
\hline \multicolumn{5}{|l|}{ Preference of tea and coffee } \\
\hline Tea & 295 & 63.3 & 158 & 46.6 \\
\hline Coffee & 171 & 36.7 & 181 & 53.4 \\
\hline Total & 466 & 100 & 339 & 100 \\
\hline \multicolumn{5}{|l|}{ Pearson $x^{2}: 22.234$, s.d:: 1, p: $0.000<0.05$} \\
\hline \multicolumn{5}{|l|}{ Things that coffee reminds } \\
\hline Cigarette & 86 & 18.4 & 118 & 34.8 \\
\hline Friend & 107 & 23.0 & 55 & 16.2 \\
\hline Chat & 213 & 45.7 & 80 & 23.6 \\
\hline Dessert & 19 & 4.1 & 42 & 12.4 \\
\hline Chocolate & 41 & 8.8 & 44 & 13.0 \\
\hline Total & 466 & 100 & 339 & 100 \\
\hline Pearson $x^{2}: 72.633$, s.d.: 4, p: $0.000<0.05$ & & & & \\
\hline
\end{tabular}

*Because multiple options are checked, the total has exceeded $100 \%$ and

$p$ value cannot be calculated

that those aged between 20 and 29 in Taiwan consume tea more than anyone else in the country [27]. In Food and Agriculture Organization (FAO) reports, young urban consumers emerge as the fastest growing segment. Particularly, young upper-middle-class income consumers are looking for stylish products and tend to consume them in the sophisticated environments of private teahouses and select restaurants, hotels and cafes [28]. In both cities, middle-income participants consume more tea or coffee than others. Approximately one-quarter of those with bottom of the middle income in İzmir visit cafes for tea and coffee. This rate is higher than those with above of the middle income. There is a difference between the participants from the two cities according to their education, occupation and income level.

The top three drinks consumed in both cities remain unchanged, but consumption rates vary. Adana mostly consumes tea and İzmir consumes Turkish coffee. When it comes to the preference of tea or coffee, tea is preferred in Adana and the participants in İzmir opt for coffee. Coffee reminds consumers of Adana mostly of chats in Adana and of smoking in İzmir (Table 2). 
Table 3 Tea consumption habits of participants

\begin{tabular}{|c|c|c|c|c|}
\hline & \multicolumn{2}{|c|}{ Adana } & \multicolumn{2}{|c|}{ İzmir } \\
\hline & $F$ & $\%$ & $F$ & $\%$ \\
\hline \multicolumn{5}{|l|}{ Consumption frequency } \\
\hline Never & 10 & 2.1 & 3 & .9 \\
\hline Once in a month & 7 & 1.5 & 30 & 8.8 \\
\hline Once/a few weeks & 79 & 16.9 & 74 & 21.8 \\
\hline $1-5$ cups per day & 276 & 59.1 & 147 & 43.4 \\
\hline 6-10 cups per day & 69 & 14.8 & 59 & 17.4 \\
\hline More than 10 cups per day & 26 & 5.6 & 26 & 7.7 \\
\hline Total & 467 & 100 & 339 & 100 \\
\hline \multicolumn{5}{|c|}{ Pearson $x^{2}: 39.008$, s.d.: $5, p: 0.000<0.05$} \\
\hline \multicolumn{5}{|l|}{ Most consumed tea } \\
\hline Black tea & 428 & 92.2 & 276 & 81.4 \\
\hline Green tea & 34 & 7.4 & 53 & 15.6 \\
\hline White tea & 2 & 0.4 & 1 & 0.3 \\
\hline Yellow tea & 0 & 0.0 & 1 & 0.3 \\
\hline Oolong tea & 0 & 0.0 & 1 & 0.3 \\
\hline Instant tea & 0 & 0.0 & 7 & 2.1 \\
\hline Total & 464 & 100 & 339 & 100 \\
\hline \multicolumn{5}{|c|}{ Pearson $x^{2}: 27.509$, s.d. $5, p: 0.000<0.05$} \\
\hline \multicolumn{5}{|c|}{ Reasons of herbal/fruit tea bags preference* } \\
\hline Be of many varieties & 114 & 24.3 & 238 & 70.2 \\
\hline Practical use & 307 & 65.5 & 207 & 61.1 \\
\hline Taste/smell/aroma & 35 & 7.5 & 26 & 7.7 \\
\hline Be healthy & 42 & 9.0 & 39 & 11.5 \\
\hline Be natural & 24 & 5.1 & 24 & 7.1 \\
\hline To lose weight & 49 & 10.4 & 65 & 19.2 \\
\hline Good for stomach problems & 40 & 8.5 & 44 & 13.0 \\
\hline \multicolumn{5}{|l|}{ Most consumed herbal/fruit tea bags } \\
\hline Linden & 157 & 34.1 & 74 & 21.8 \\
\hline Sage & 65 & 14.1 & 50 & 14.7 \\
\hline Rosehip tea & 89 & 19.3 & 57 & 16.8 \\
\hline Green tea & 79 & 17.1 & 77 & 22.7 \\
\hline Camomile & 9 & 2.0 & 29 & 8.6 \\
\hline Blackberry & 11 & 2.4 & 2 & 0.6 \\
\hline Fennel & 4 & 0.9 & 6 & 1.8 \\
\hline Apple & 11 & 2.4 & 7 & 2.1 \\
\hline Lemon & 10 & 2.2 & 12 & 3.5 \\
\hline Mint & 7 & 1.5 & 21 & 6.2 \\
\hline Herbal slimming teas & 9 & 2.0 & 4 & 1.2 \\
\hline Other & 10 & 2.2 & 0 & 0 \\
\hline Total & 461 & 100 & 339 & 100 \\
\hline \multicolumn{5}{|c|}{ Pearson $x^{2}: 58.730$, s.d.: $11, p: 0.000<0.05$} \\
\hline \multicolumn{5}{|c|}{ Reasons not to prefer of herbal/fruit tea bags* } \\
\hline Unfavourable taste/smell/aroma & 153 & 32.6 & 67 & 19.8 \\
\hline Dislike the use of tea bags & 148 & 31.6 & 83 & 24.5 \\
\hline No habit of using tea bags & 58 & 12.4 & 98 & 28.9 \\
\hline Non-economic & 35 & 7.5 & 58 & 17.1 \\
\hline Not natural & 91 & 19.4 & 97 & 28.6 \\
\hline Not quality & 38 & 8.1 & 62 & 18.3 \\
\hline
\end{tabular}

*Because multiple options are checked, the total has exceeded $100 \%$ and $p$ value cannot be calculated
Results regarding the tea consumption habits

The findings regarding the tea consumption habits of the participants are summarized in Table 3. As the table shows, $59.1 \%$ of the participants in Adana and $43.4 \%$ of the participants in İzmir consume between 1 and 5 cups of tea per day. Black tea is the most common tea used for brewing tea in both provinces, and this is followed by green tea. This may be due to the positive effects of green tea on health. Green tea lowers both body fat and cholesterol levels [29], and drinking a few cups of green tea every day can prevent cancer [4]. While yellow tea, Oolong tea and instant tea are not consumed in Adana at all, they are consumed very little in İzmir. This finding is similar to Gunes' [9] finding that $95 \%$ of the consumed tea is classic black tea and the remaining $5 \%$ is tea bag. Mainly brewing method in black tea is used in both cities (A: \%57, I: \%47). The most preferred four types of herbal/ fruit tea bags are linden, sage, rosehip and green tea. In Adana, people mostly use linden, whereas in İzmir green tea is preferred. In recent years, interest in high-quality specialty teas is increasing. Particularly, green tea, herbal teas and fruit tea have several health benefits; therefore, product variety and accessibility have also increased. All of this characterizes a tea market that attracts an increasing number of young customers and a developing middle-income class [6]. There is a difference in the tea consumption frequency of the participants of the two cities, the tea they consume the most, and the herbal/fruit tea varieties $(p<0.05)$.

While the most important factor in prefer of herbal/ fruit tea bag in Adana is practical usage, it is preferred for practicality and rich variety in İzmir. Approximately one-fifth of the participants in İzmir prefer tea bag to lose weight. In Adana, tea bags are not preferred due to its taste, smell and aroma. Also, some people reported not to enjoy the tea bags as much as the leaf tea. On the other hand, in İzmir, there is no habit of using tea bags because of thinking they are not natural. The new market trends in the beverage sector show that consumers prefer tea as a healthier alternative to other beverages such as fizzy drinks. Ready-to-drink teas and new tea products with high added value such as fruity and flavoured teas increased green tea consumption outside Asia [6].

\section{Results regarding the coffee consumption habits}

The rate of participants who say that they cannot start the day without drinking coffee is $22.4 \%$ in İzmir and $23.7 \%$ in Adana. Table 4 presents participants' coffee consumption habits. Accordingly, approximately half of the participants in Adana consume coffee once or several 
Table 4 Coffee consumption habits of participants

\begin{tabular}{|c|c|c|c|c|}
\hline & \multicolumn{2}{|c|}{ Adana } & \multicolumn{2}{|c|}{ İzmir } \\
\hline & $F$ & $\%$ & $F$ & $\%$ \\
\hline \multicolumn{5}{|l|}{ Consumption frequency } \\
\hline Never & 11 & 2.3 & 2 & 0.6 \\
\hline Once in a month & 45 & 9.6 & 18 & 5.3 \\
\hline Once/a few weeks & 240 & 51.4 & 102 & 30.1 \\
\hline $1-5$ cups per day & 161 & 34.5 & 184 & 54.3 \\
\hline 6-10 cups per day & 6 & 1.3 & 25 & 7.4 \\
\hline More than 10 cups per day & 4 & 0.9 & 8 & 2.4 \\
\hline Total & 467 & 100 & 339 & 100 \\
\hline \multicolumn{5}{|l|}{ Pearson $x^{2}: 69.422$, s.d.5, p: $0.000<0.05$} \\
\hline \multicolumn{5}{|l|}{ Consumption venue } \\
\hline Home & 209 & 45.0 & 111 & 32.7 \\
\hline Coffee shops & 131 & 28.2 & 126 & 37.2 \\
\hline Trip/Picnic & 7 & 1.5 & 1 & 0.3 \\
\hline Workplace & 67 & 14.4 & 75 & 22.1 \\
\hline Beach & 3 & 0.6 & 2 & 0.6 \\
\hline Social surroundings & 41 & 8.8 & 16 & 4.7 \\
\hline Travel & 7 & 1.5 & 8 & 2.4 \\
\hline Total & 465 & 100 & 339 & 100 \\
\hline \multicolumn{5}{|l|}{ Pearson $x^{2}: 27.214$, s.d.:6, p: $0.000<0.05$} \\
\hline \multicolumn{5}{|l|}{ Coffee consumption in home } \\
\hline Turkish coffee & 378 & 81.3 & 175 & 51.6 \\
\hline Espresso & 6 & 1.3 & 2 & 0.6 \\
\hline Filter coffee & 19 & 4.1 & 40 & 11.8 \\
\hline Decaf coffee & 3 & 0.6 & 1 & 0.3 \\
\hline Instant coffee & 29 & 6.2 & 109 & 32.1 \\
\hline Mocha & 4 & 0.9 & 1 & 0.3 \\
\hline Americano & 7 & 1.5 & 0 & - \\
\hline Latte & 13 & 2.8 & 4 & 1.2 \\
\hline Macchiato & 1 & 0.2 & 3 & 0.9 \\
\hline Frappuccino & 0 & - & 2 & 0.6 \\
\hline Cappuccino & 5 & 1.1 & 2 & 0.6 \\
\hline Total & 465 & 100 & 339 & 100 \\
\hline \multicolumn{5}{|l|}{ Pearson $x^{2}: 133.508$, s.d.: $11, p: 0.000<0.05$} \\
\hline \multicolumn{5}{|l|}{ Consumption time } \\
\hline Morning & 131 & 28.2 & 64 & 18.9 \\
\hline Mid-morning & 26 & 5.6 & 22 & 6.5 \\
\hline Noon & 99 & 21.3 & 140 & 41,3 \\
\hline Evening & 156 & 33.5 & 92 & 27.1 \\
\hline Mid-afternoon & 32 & 6.9 & 9 & 2.7 \\
\hline Night & 21 & 4.5 & 12 & 3.5 \\
\hline Total & 465 & 100 & 339 & 100 \\
\hline \multicolumn{5}{|l|}{ Pearson $x^{2}: 43.585$, s.d.:5, p: $0.000<0.05$} \\
\hline \multicolumn{5}{|l|}{ Coffee density } \\
\hline Light and soft & 55 & 11.8 & 59 & 17.4 \\
\hline Medium and balanced & 351 & 75.3 & 210 & 61.9 \\
\hline Dense and hard & 60 & 12.9 & 70 & 20.6 \\
\hline Total & 466 & 100 & 339 & 100 \\
\hline Pearson $x^{2}: 16.728$, s.d.:2, p: $0.000<0.05$ & & & & \\
\hline
\end{tabular}

Table 4 (continued)

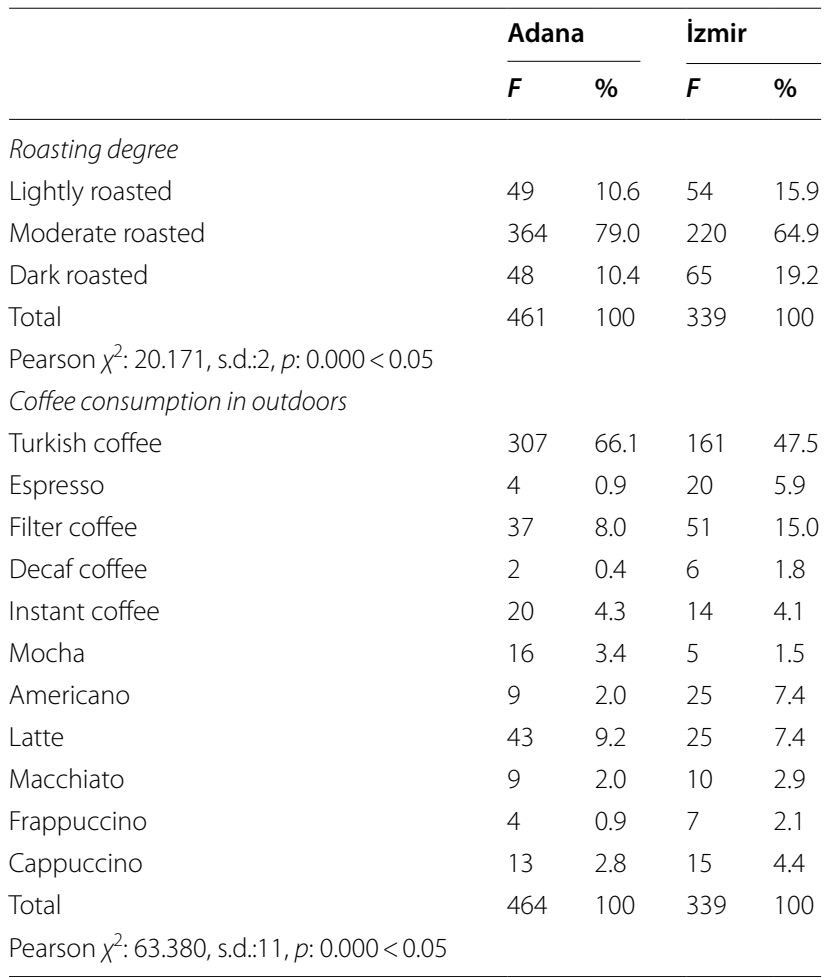

times a week, while in İzmir more than half consume one to five cups of coffee per day. The ratio of those who do not consume any coffee is higher in Adana. Based on these results, it is possible to say that coffee consumption is higher in İzmir.

In terms of consumption of coffee during the day, the coffee is mostly preferred in evening and later in the morning in Adana, while people mostly consume coffee at noon in İzmir. The research on coffee consumption determined that the most important time of the day for drinking coffee was breakfast [30]. In Adana, coffee is mostly consumed at home and secondly in coffee shops, while this is vice versa in İzmir. It is also consumed in the workplace. Mostly, moderate roasted coffee is consumed in both cities. However, one-fifth of the participants prefer dark roasted coffee in İzmir. The top three coffee houses visited by participants are Kahve Dünyası (Turkish brand), Starbucks and Gönül Kahvesi (Turkish brand). In Adana, only $32.2 \%$ of the participants tried international regional coffees and Colombian coffee was the most popular one. $49 \%$ of the participants in İzmir prefer 3-in-1 instant coffee and mostly opt for chocolate aroma. Additionally, in both Adana $(81.3 \%$ at home; $66.1 \%$ outdoors) and İzmir (51.6\% at home; $47.5 \%$ outdoors), Turkish coffee is the most widely consumed coffee. These results are similar to those of Ulusoy [24]. 
The researcher stated that the Turkish coffee culture is very popular, although there is little publicity compared to foreign coffee and beverage types. However, the tendency to consume new coffee varieties, especially outdoors, is also common in İzmir. These results show that İzmir, located in the west of Turkey, is more adapted to new trends. Although globalization creates a common perception that threatens local gastronomic identity and image, it may also provide discovery of local gastronomic products and identity [31].

Table 5 presents consumption preferences of the participants regarding Turkish coffee. In Adana, copper coffee pots are preferred in Turkish coffee making. In İzmir, although there is no clear distinction, about one-third of

Table 5 Participants' consumption habits of Turkish coffee

\begin{tabular}{|c|c|c|c|c|}
\hline & \multicolumn{2}{|c|}{ Adana } & \multicolumn{2}{|c|}{ İzmir } \\
\hline & $F$ & $\%$ & $F$ & $\%$ \\
\hline \multicolumn{5}{|l|}{ Cooking tools } \\
\hline Copper coffee pot & 266 & 58.0 & 108 & 31.9 \\
\hline Steel coffee pot & 82 & 17.9 & 106 & 31.3 \\
\hline Electric coffee pot & 44 & 9.6 & 79 & 23.3 \\
\hline Turkish coffee machine & 67 & 14.5 & 46 & 13,6 \\
\hline Total & 459 & 100 & 339 & 100 \\
\hline \multicolumn{5}{|c|}{ Pearson $x^{2}: 67.148$, s.d.:3, p: $0.000<0.05$} \\
\hline \multicolumn{5}{|l|}{ Sugar ratio } \\
\hline Black & 84 & 18.3 & 55 & 16.2 \\
\hline A little sugary & 75 & 16.3 & 70 & 20.6 \\
\hline Medium sugary & 243 & 52.8 & 145 & 42.8 \\
\hline Sugary & 50 & 10.9 & 56 & 16.5 \\
\hline Well-sugary & 8 & 1.7 & 13 & 3.8 \\
\hline Total & 460 & 100 & 339 & 100 \\
\hline \multicolumn{5}{|c|}{ Pearson $x^{2}: 14.514$, s.d.: 4 , p: $0.006<0.05$} \\
\hline \multicolumn{5}{|l|}{ How it is made } \\
\hline On ember & 271 & 59.3 & 116 & 34.2 \\
\hline On the cooker & 81 & 17.8 & 119 & 35.1 \\
\hline Machine & 39 & 8.5 & 86 & 25.4 \\
\hline On sand & 66 & 14.4 & 18 & 5.3 \\
\hline Total & 457 & 100 & 339 & 100 \\
\hline \multicolumn{5}{|c|}{ Pearson $x^{2}: 99.086$, s.d.3, $p: 0.000<0.05$} \\
\hline \multicolumn{5}{|l|}{ Coffee types* } \\
\hline With milk & 218 & 46.5 & 101 & 29.8 \\
\hline With mastic & 206 & 43.9 & 205 & 60.5 \\
\hline Myrrh & 61 & 13.0 & 60 & 17.7 \\
\hline Dibek (Mortar) & 77 & 16.4 & 88 & 26.0 \\
\hline Menengiç & 136 & 29.0 & 28 & 8.3 \\
\hline Cilveli** & 12 & 2.6 & 32 & 9.4 \\
\hline
\end{tabular}

*Multiple options are checked, the total has exceeded $100 \%$ and $p$ value cannot be calculated

**It is obtained by adding a mixture of double roasted, ground almonds and two kinds of spices to the surface of the frothy Turkish coffee the participants prefer copper or steel coffee pots, while about a quarter prefer electric coffee pot. Copper coffee pot has a long handle that makes it easy to keep it on fire, a large base for making the best use of the heat of the fire, and a beak mouth used for pouring coffee into the cup [18]. While 59.3\% of the participants in Adana prefer Turkish coffee on ember, it is more widely used to make coffee on the cooker in İzmir. This may be related to the barbecue culture of Adana. In both cities, participants consume coffee with medium sugar. In Adana, milk, mastic or menengiç flavours are used for Turkish coffee, whereas in İzmir, mastic, milk and dibek are preferred.

\section{Conclusions}

The use of traditional food as a gastronomic element due to the competition conditions of the business is an important issue in ensuring differences in destinations. Therefore, it can be used as a method in tourism marketing by promoting local food traditions and customs such as tea and coffee consumption and increasing their gastronomic value. Tea and Turkish coffee as the traditional drinks of Turkey are the main cultural indicators of marketing strategies. The research shows that participants prefer Turkish coffee and tea compared to the foreign coffee and beverage types. This is important in terms of ensuring the sustainability of traditional drinks in tourism and the value of such traditional beverages as gastronomic attraction. The participants often visit local coffee businesses, which shows the desire to combine traditional line and new trends in both cities.

In Adana, participants' desire to make coffee with traditional method, using copper coffee pots, is an indication that Turkish coffee culture can be preserved and transferred to future generations. Especially in multinational enterprises, it is important to pay attention to the traditional way of preparation of coffee for the purposes of tourism marketing. Also, we can argue that local people maintain traditional way of brewing tea and hold on to their cultural traditions. On the other hand, tea should be considered not only in terms of its economic contribution to the enterprises but also in terms of producers. Especially in the Black Sea region, it is recommended to develop tea tourism and increase the number of tourists who come to the province for tea. A tea museum can be a good starting point to promote cultural and tourism visits.

It is possible to use the different types of coffee depending on the regions in Turkey as a means of differentiating the destinations and to register them as geographically marked products. The geographical indication of the gastronomic products is not at the desired level. The fact that the "national registration" of Turkish coffee (10.09.2012) [32], which has a history of at least 600 years, is still at the application stage 
and the registration of black tea as "Rize Tea" [33] has just been made in 2021, in fact, is an indication that the protection measures have been delayed. However, the geographical indication system protects regional tradition and culture from the negative effects of globalization [34].

These results show that the changing consumption habits with globalization do not negatively affect Turkey's traditional tea and coffee culture. As a result, although the traditions of coffee and tea are still maintained in the country, new trends in consumption outdoor may be preferred more in the west of the country. Global brands also benefit from the local characteristics of countries while developing their marketing strategies. Therefore, it would be beneficial for both local and multinational beverage establishments to include traditional beverages in their menus and to increase the number and variety of these beverages. This will also promote Turkish coffee and tea to foreign tourists.

\section{Authors' information}

Dr. Oya Yildirim is a Lecturer at Accommodation Management Department School of Tourism and Hotel Management in Cukurova University. Dr. Yildirim published 16 international and national articles, 15 conference papers and 4 book chapters. In addition, she took part in one project as a researcher. Her research interests are tourism marketing, sustainable tourism, tourism and environment, cultural heritage, event and gastronomic tourism

Dr. Oya Berkay Karaca is a Professor at School of Tourism and Hotel Management in Cukurova University. She is experienced and oft published researcher in the field of gastronomy. Dr. Karaca published 52 international and national articles, 53 papers, 5 chapters and 1 book. In addition, she took part in 20 projects as a director and/or researcher. The book "Traditional Cheeses from Selected Regions in Asia, Europe and South America" won the best of the world prize in the Dairy \& Cheese category in the 25th Gourmand World Cookbook Awards 2020 competition. She has two international scholarships, five publication encouragement awards and two Bachelor's graduation degrees (the first degree in the department and the second degree in the Faculty).

\section{Authors' contributions}

All authors contributed equally to the article. All authors read and approved the final manuscript.

\section{Funding}

Not applicable. This research did not receive any specific grant from funding agencies in the public, commercial, or not-for-profit sectors.

\section{Availability of data and materials}

The data collected through questionnaires in this study were transferred to a computer program and are kept by the authors.

\section{Declarations}

\section{Competing interests}

All contributing authors declare no conflicts of interest.

Received: 27 September 2021 Accepted: 14 February 2022 Published online: 03 March 2022

\section{References}

1. United Nations Educational, Scientific, and Cultural Organization (UNESCO). Convention for the safeguarding of the intangible cultural heritage [document on the Internet]. UNESCO;2003 [cited 2019 Sep 20] Available from: https://unesdoc.unesco.org/ark:/48223/pf0000132540.

2. Kelemci Scheneider G, Ceritoglu AB. The role of the local products in a global world - an investigation in İstanbul. Pazarlama ve Pazarlama Araştırmaları Dergisi. 2010;6:29-52.

3. Asker A. Global-local interaction: the "fast-foodization" of simit (savory roll covered with sesame seed) as the transformation of local in the case of Simit Sarayı. Erciyes Illetişim Dergisi Academia. 2011;2(1):88-104.

4. Su SW. Tea or coffee: a study of the beverage choice pattern and its affecting factors at teatime in Kaohsiung, Taiwan. Asia Pacific Manag Rev. 2007;12(4):245-57.

5. Einöther SJL, Rowson M, Ramaekers JG, Giesbrecht T. Infusing pleasure: mood effects of the consumption of a single cup of tea. Appetite. 2016:103:302-8.

6. Food and Agriculture Organization (FAO). Intergovernmental group on tea, emerging trends in tea consumption: informing a generic promotion process, Hangzhou, the people's Republic of China [document on the Internet]. FAO;2018 [cited 2019 Sep 20]. Available from: http://www.fao. org/3/MW522EN/mw522en.pdf.

7. Çay İşletmeleri Genel Müdürlüğü. Türkiye çay sektörü raporu 2019. [data table online]. [cited 2021 Dec 26]. Available from: https://www.caykur. gov.tr/Pages/Yayinlar/YayinDetay.aspx?ltemType $=5 \&$ ltemld $=721$.

8. Tarımsal Ekonomi ve Politika Geliştirme Enstitüsü (TEPGE). Tarım ürünleri piyasa raporu, 2021. Çay, [document on the Internet]. TEPGE;2021 [cited 2021 Dec 26]. Available from: https://arastirma.tarimorman.gov.tr/tepge/ Belgeler/PDF\%20Tar\%C4\%B1 m\%20\%C3\%9Cr\%C3\%BCnleri\%20Piyasalar\% C4\%B1/2021-Haziran\%20Tar\%C4\%B1 m\%20\%C3\%9Cr\%C3\%BCnleri\% 20Raporu/\%C3\%87ay,\%20Haziran-2021,\%20Tar\%C4\%B1 m\%20\%C3\% 9Cr\%C3\%BCnleri\%20Piyasa\%20Raporu,\%20TEPGE.pdf

9. Gunes S. Turkish tea culture and its product. Millî Folklor. 2012;24(93):234-51.

10. Köprülü MF. Türk edebiyatında ilk mutasavvıflar. Ankara: Akçağ Publishing; 2003

11. Boltanski L, Chiapell OE. Le nouvel esprit du capitalisme. Paris: Gallimard; 1999.

12. Gürsoy D. Deniz Gürsoy's gastronomy history. Istanbul: Oglak Publishing Advertising; 2014

13. Akarcay E. Sometimes coffehouse sometimes café: a theoretical introduction to coffee consumption in globalizing Eskişehir. Galatasaray Üniversitesi Illetişim Dergisi. 2012;2:181-202.

14. Adalı Aydın G, Bakır ZN. An assessment of venues in the context of consumption culture: consumption of kahve cafe(s) by college students. J Strateg Res Soc Sci. 2016;2(3):59-84.

15. Tezcan M. Türk yemek antropolojisi yazıları. Ankara: Kültür Bakanlığı Publishing; 2000.

16. United Nations Educational, Scientific, and Cultural Organization (UNESCO). Turkish coffee culture and tradition (No. 00645) [document on the Internet],) [accessed 10 Dec 2021]. UNESCO;2013 [cited 2019 Sep 23]. Available from: https://ich.unesco.org/en/RL/turkish-coffee-culture-andtradition-00645.

17. United Nations Educational, Scientific, and Cultural Organization (UNESCO). The gastronomic meal of the French (No. 00437) [Internet], [accessed 01 Jan 2022]. Available from: http://www.unesco.org/culture/ ich/en/d\%C3\%A9cisions/5.COM/6.14.

18. Yilmaz B, Acar-Tek N, Sözlü S. Turkish cultural heritage: a cup of coffee. J Ethn Foods. 2017:4(4):213-20.

19. Ayvazoğlu B. Turkish coffee culture. "a cup of coffee commits one to forty years of friendship". Ankara: Republic of Turkey Ministry of Culture and Tourism General Directorate of Libraries and Publications; 2011.

20. Çelik I, Karahançer H, Laz C. Anadolu'daki yöresel kahve çeşitleri. 4. Geleneksel Gıdalar Sempozyumu, 17-19 April 2014, Adana, Turkey, 236-39.

21. Ökeli H. Arabica ve Robusta arasındaki 10 fark. Kahve Hakkında Her Şey. 2015;23:126.

22. Hepsağ F, Hepsağ B, Hayoğlu İ. Çedene kahvesi. 4. Geleneksel Gıdalar Sempozyumu, Adana, Turkey; 2014. p. 103-5.

23. Bozkurt A, Akbulut Ç. Nohut kahvesi. 4. Geleneksel Gıdalar Sempozyumu, Adana, Turkey; 2014. p. 626.

24. Ulusoy K. Coffee and coffeehouse culture in Turkish Society (A verbal culture and social environmental education study). Millî Folklor. 2011;23(89):159-69. 
25. Karakundakoglu GM. Türkiye ve dünyada kahve. Food Sektör Dergisi [newspaper online]. 2019 Apr 5 [cited 2019 Oct 9]. Available from: http:// foodsektor.com/mobil/haber/576/turkiye-ve-dunyada-kahve.html.

26. Türkiye İstatistik Kurumu (TUIK). Adrese dayalı nüfus kayıt sistemi sonuçları, 2020 [data table online]. [cited 2021 Sep 24]. Available from: https://data.tuik.gov.tr/Bulten/Index?p=Adrese-Dayalı-Nüfus-Kayıt-Siste mi-Sonuçları-2020-37210\&dil=1.

27. Lee CW, Liao CS. The effects of consumer preferences and perceptions of Chinese tea beverages on brand positioning strategies. Br Food J. 2009;111(1):80-96.

28. Food and Agriculture Organization (FAO). Global tea consumption and production driven by robust demand in China and India [document on the Internet]. FAO;2019 [cited 2019 Sep 20]. Available from: http://www. fao.org/news/story/en/item/1136255/icode/.

29. Nagao T, Komine Y, Soga S, Meguro S, Has T, Tanaka Y, Tokimitsu I. Ingestion of a tea rich in catechins leads to a reduction in body fat and malondialdehyde-modified LDL in men. Am J Clin Nutr. 2005;81(1):122-9.

30. Samoggia A, Riedel B. Coffee consumption and purchasing behaviour review: insights for further research. Appetite. 2018;129:70-81.

31. Mak AHN, Lumbers M, Eves A. Globalisation and food consumption in tourism. Ann Tour Res. 2012;39(1):171-96.

32. Turkish patent and trademark institution. Turkish coffee [Internet], [accessed 01 Jan 2022]. Available from: https://ci.turkpatent.gov.tr/cogra fi-isaretler/detay/38076.

33. Turkish patent and trademark institution. Rize Tea [Internet], [accessed 01 Jan 2022]. Available from: https://ci.turkpatent.gov.tr/cografi-isaretler/ detay/38339

34. Sato J, Kohsaka R. Japanese sake and evolution of technology: a comparative view with wine and its implications for regional branding and tourism. J Ethn Foods. 2017;4:88-93.

\section{Publisher's Note}

Springer Nature remains neutral with regard to jurisdictional claims in published maps and institutional affiliations.

- fast, convenient online submission

- thorough peer review by experienced researchers in your field

- rapid publication on acceptance

- support for research data, including large and complex data types

- gold Open Access which fosters wider collaboration and increased citations

- maximum visibility for your research: over $100 \mathrm{M}$ website views per year

At BMC, research is always in progress.

Learn more biomedcentral.com/submissions 